\title{
REFLEXÕES SOBRE OS LIMITES DOS EFEITOS DA REVELIA
}

\section{REFLECTIONS ABOUT THE LIMITS OF THE EFFECTS TO THE DEFAULT}

\author{
Ravi Peixoto ${ }^{1}$
}

\section{RESUMO}

O texto tem por objetivo analisar o instituto da revelia, em especial os seus efeitos e limites. No direito processual civil brasileiro, réu revel tem sobre si dois efeitos consideravelmente prejudiciais, deixando de ser intimados dos atos decisórios e tendo contra si a presunção relativa de veracidade dos fatos. Propõe-se, então, a investigação dos limites desses efeitos.

Palavras-chave: Contumácia; Revelia; Efeito material; Efeito processual; Limites.

\section{ABSTRACT}

The article aims to study the institute of default, specially its effects and limits. In the Brazilian civil procedural law, the default defendant suffers two very prejudicial effects, because he won't have the right to get a notice from the judicial decisions and will have against him the presumption of truth about the facts. The main objective is to study the limits of those effects.

Keywords: Contumacy; Default; Material Effect; Procedural effects; Limits.

\section{INTRODUÇÃO}

No processo civil, a revelia consiste na ausência de apresentação tempestiva da contestação. Como ressalta Dinamarco (2017, p. 605), podem não ocorrer, por diversos motivos, os efeitos da revelia, no entanto, a parte que não contesta é revel. Em outros termos, a revelia é o nome dado a um comportamento omissivo específico no processo (não apresentação tempestiva da contestação), sendo possível afirmar ser ela uma espécie de contumácia (SOUZA, 2003, p. 182183; GIANESINI, 1977, p. 54-66). ${ }^{2}$

Dessa forma, por exemplo, a não apresentação de impugnação ao cumprimento de sentença ou mesmo a não apresentação dos embargos ao mandado monitório, pois que possam ter até efeitos mais danosos ao réu omisso, não podem ser tidos como situações de revelia. Trata-se de situação na qual há simplesmente contumácia, sem qualquer denominação específica (DINAMARCO, 2017, p. 605), a qual pode ter inúmeros efeitos diferentes.

Cada uma das omissões processuais pode ter efeitos diferentes, mas, no caso da revelia, estes são consideravelmente drásticos, envolvendo a presunção relativa de veracidade das hipóteses fáticas narradas pelo autor e a dispensa de intimação do réu. Ocorre que esses efeitos, em especial, o efeito material é capaz de trazer grandes prejuízos ao réu por uma simples omissão e vem sendo discutido, na doutrina e na jurisprudência, diversas formas de sua mitigação.

Esse é o principal objetivo do texto: rediscutindo o tema da revelia e os seus efeitos, propor

${ }^{1}$ Doutor em direito processual pela UERJ. Mestre em Direito pela UFPE. Procurador do Município do Recife. Advogado. Membro da ANNEP, do CEAPRO, da ABDPRO e do IBDP. E-mail: ravipeixoto@gmail.com ${ }^{2}$ Sobre a contumácia, cf. CUNHA, 2013. 
reflexões sobre os limites dos efeitos dessa omissão processual específica.

\section{A REVELIA NA TEORIA DO FATO JURÍDICO}

$\mathrm{Na}$ teoria do fato jurídico, tem-se, como uma espécie de fato jurídico o ato-fato jurídico processual, em que há a participação de ato humano, mas a manifestação de vontade em sua realização é desprezada pelo direito, ou seja, não ingressam no plano da validade. Podem ser citados como exemplos tanto o reexame necessário, onde suas hipóteses de cabimento são definidas em lei, independendo do interesse de qualquer das partes em aplicá-lo ou não, a contumácia.

A revelia, como espécie de contumácia, é considerada como um ato-fato (DIDIER JR., 2018, p. 767), ou seja, a vontade daquele sujeito é irrelevante. Não importa se, na sua intimidade, o réu concorda com as alegações do autor ou simplesmente esqueceu de contestar. A consideração de que não importa a vontade do réu é importante e gera diversos efeitos, como a possibilidade de intervenção posterior do réu revel, a possibilidade de produção de provas, de apresentação de recursos etc. Caso a vontade do réu fosse relevante na caracterização da revelia, qualquer ato posterior que viesse a impugnar a pretensão autor lhe seria vedado, porque seria venire contra factum proprium.

\section{REQUISITOS PARA O RECONHECIMENTO DA REVELIA}

\section{a. Citação válida}

Para que o réu possa sofrer os efeitos da revelia, a citação deve ser válida. De acordo com o STJ, não é imprescindível a indicação, no mandado, do prazo para contestação e da advertência quanto ao efeito da revelia. Em outros termos, a citação seria válida e o réu poderia ter sua revelia decretada, mesmo que não houvesse indicação, no mandado de sua possibilidade. Prevaleceu o entendimento de que esse defeito na citação apenas geraria decretação de sua nulidade caso demonstrado o prejuízo. Essa decretação da nulidade apenas ocorreria, por exemplo, "hipótese de réu humilde, sem experiência da lide jurisdicional, que, eventualmente, tardasse a procurar aconselhamento especializado de advogado". Não seria, por exemplo, a situação no caso analisado, referente a empresa com milhares de demandas e com plenas condições de ter conhecimento dos efeitos da não apresentação da contestação (STJ, $2^{a}$ T., REsp 1.130.335/RJ, Rel. Min. Herman Benjamin, j. 18/02/2010, DJe 04/03/2010). Em sentido contrário, apesar de criticar a opção legal, exigindo que haja expressa manifestação no mandado de que a não apresentação tempestiva da defesa configura revelia, embora não haja necessidade de menção aos seus efeitos: YARSHELL; PEREIRA; RODRIGUES, 2018, art. 344, item 4.

\section{b. Citação real}

Apenas o réu que seja citado de forma real será considerado revel. Quando a citação for ficta, o que ocorre na citação por edital ou por hora certa, haverá nomeação de curador especial (art. 72, II, CPC). Isso porque, como nesses casos há incerteza quanto ao conhecimento do réu acerca do processo, a legislação opta por impedir a aplicação dos efeitos da revelia mediante a nomeação de um curador especial para que atue nos autos, apresentando, por exemplo, a contestação.

\section{EFEITOS DA REVELIA}

A revelia possui dois efeitos principais, quais sejam: i) o efeito processual, que significa que os prazos irão fluir da data de publicação do ato decisório no órgão oficial, dispensada sua intimação (art. 346, CPC), desde que o réu não tenha patrono nos autos e ii) efeito material, que 


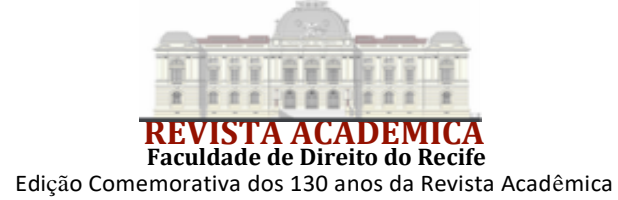

significa a presunção relativa de veracidade das alegações de fato do autor (art. 344). ${ }^{3}$

Importa destacar que uma coisa é a caracterização do réu como revel: não apresentação de contestação tempestiva e outra é a produção dos seus efeitos. Os arts. 345 e 346 apontam situações que podem elidir a produção de efeitos materiais e processuais da revelia.

Há, ainda, outro efeito da revelia, que é a possibilidade de criação de atalhos no procedimento comum. Em regra, após a apresentação da contestação, o processo entra na fase de realização das providências preliminares, saneamento e produção das provas. Se há revelia, mas não há produção dos efeitos materiais (art. 348, CPC) ou o réu intervém no processo a tempo (art. 349, CPC), haverá oportunização da produção de provas pelas partes.

Por outro lado, se há produção dos efeitos materiais, cria-se um outro caminho no procedimento comum, permitindo o julgamento antecipado do mérito (art. 355, II, CPC). Apontese que pode ocorrer de haver julgamento antecipado, mesmo nos casos em que não esteja presente o efeito material da revelia (ASSIS, 2015, p. 376-377). É possível imaginar ação de responsabilidade civil ajuizada contra ente público baseada na responsabilidade civil objetiva (art. $37, \S 6^{\circ}, \mathrm{CF}$ ) na qual inexista necessidade de produção de novas provas. Afinal, nesses casos, como é desnecessária a comprovação da culpa ou dolo, basta à parte comprovar o nexo causal e o dano. Também é possível por decorrência da produção dos efeitos materiais da revelia, mas apenas em relação a um dos pedidos, o julgamento antecipado parcial do mérito, nos termos do art. 356, II, CPC.

Há ainda uma última consequência da revelia, que é a vedação da extensão da coisa julgada à questão prejudicial incidental por expressa previsão legal (art. 503, §1 $1^{\circ}, \mathrm{II}, \mathrm{CPC}$ ).

\section{EFEITO MATERIAL DA REVELIA}

$\mathrm{O}$ art. 344 do CPC afirma que o efeito material da revelia consiste na presunção de veracidade dos fatos alegados pelo autor. Ocorre que essa presunção é relativa e não absoluta. Ou seja, a revelia não transforma o quadrado em um círculo, não permite que torne verdadeira a narrativa de que, por exemplo, os danos causados no veículo do autor foram de responsabilidade de uma raça alienígena que o persegue.

Como sempre ressaltado pelo STJ, “A caraterização da revelia não conduz a uma presunção absoluta de veracidade dos fatos narrados pelo autor, permitindo ao juiz, para formar o seu convencimento, que analise as alegações formuladas pelas partes em confronto com as provas constantes dos autos" (STJ, $3^{\mathrm{a}}$ T., AgInt no AREsp 1.383.629/SC, Rel. Min. Ricardo Villas Bôas Cueva, j. 13/05/2019, DJe 21/05/2019).

Uma constatação importante é a de que "A decretação da revelia do réu não resulta, necessariamente, em procedência do pedido deduzido pelo autor, sobretudo quando ausente a prova dos fatos constitutivos alegados na petição inicial”. (STJ, $3^{\mathrm{a}}$ T., REsp 1.732.807-RJ, Rel. Min. Nancy Andrighi, por unanimidade, j. 14/08/2018, DJe 17/08/2018, info. n. 631).

É relevante destacar que a presunção relativa de veracidade dos fatos alegados pelo autor não é um efeito especial da revelia. Ele pode ocorrer em outras situações, como na ausência de impugnação especificada dos fatos (art. 341, CPC), ou mesmo na hipótese confissão dos fatos pelo réu.

\section{a. Apresentação intempestiva da contestação. Revelia. Efeitos.}

Como apontado, a revelia consiste em não apresentação tempestiva da contestação. Assim, a apresentação, mesmo que intempestiva da contestação não impede que o réu seja caracterizado como revel.

Em tal situação, prevalece no STJ a posição de que “A contestação juntada posteriormente

${ }_{3}^{3}$ Para uma defesa da inconstitucionalidade dos efeitos da revelia, cf. SOUZA, 2003, p. 233-261. 


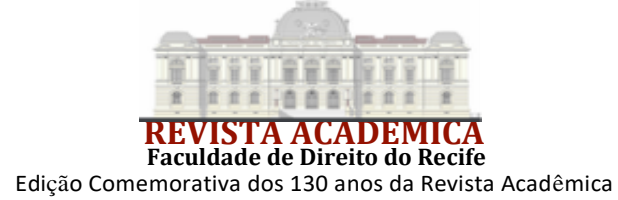

ao decurso do prazo legal pode ser desentranhada dos autos". (STJ, $3^{\text {a }}$ T., AgRg no AREsp 129.065/SP, Rel. Min. Paulo De Tarso Sanseverino, j. 17/10/2013, DJe 25/10/2013; STJ, $3^{\mathrm{a}}$ T., AgRg no REsp 799.172/MT, Rel. Min. Aldir Passarinho Junior, j. 06/08/2009, DJe 08/09/2009). Nos tribunais locais, o entendimento varia, pois há julgados do TJMG que impedem o desentranhamento da contestação intempestiva (TJ-MG - AI: 10024112861711001 MG, Rel. Des. Amorim Siqueira, j. 24/11/2015, DJ 03/12/2015). No mesmo sentido e a posição do TJRS, sob o fundamento de que "Os efeitos da revelia somente operam quanto à matéria de fato e não no que respeita à matéria de direito. Por isso, é possível mesmo sendo intempestiva a contestação, o recebimento e a análise dos documentos com ela juntados" (TJ-RS, 11 ${ }^{\mathrm{a}}$ C. Cível. - AI: 70038283933 RS, Rel. Des. Antônio Maria Rodrigues de Freitas Iserhard, j. 13/09/2010, DJ 23/09/2010). De forma semelhante é a posição do TJGO (TJ-GO, 2 ${ }^{\text {a }}$ C. Cível, AI: 04248273820108090000 GOIANIA, Rel. Des. João Waldeck Felix De Sousa, j. 22/02/2011, DJ 779 de 16/03/2011).

$\mathrm{Na}$ doutrina, o entendimento parece ser no sentido de não se admitir o desentranhamento da contestação. Para Andre Roque, não deve ser desentranhada nos casos em que a contestação “(i) contiver defesas que podem ser suscitadas mesmo após o prazo da contestação (art. 342), em especial as preliminares relacionadas no art. 337; (ii) demonstrar que os fatos articulados pelo autor são implausíveis ou elidir a presunção de veracidade decorrente da revelia (art. 345, IV); (iii) divergir das conclusões jurídicas pleiteadas pelo autor, sobre as quais não recairão os efeitos da revelia" (2021, p. 526). No mesmo sentido afirma Bedaque, pois, uma vez que a revelia não gera uma presunção absoluta, a contestação pode gerar dúvidas no juiz em relação aos fatos narrados pelo autor (2006, p. 141).

\section{LIMITAÇÕES AOS EFEITOS MATERIAIS DA REVELIA}

A revelia nem sempre irá gerar a presunção de veracidade dos fatos narrados do autor, conforme elencadas no art. 345. Ocorre que, como veremos, a previsão legal não é taxativa, mas exemplificativa, pois há várias situações nas quais há revelia, não há inserção em nenhuma hipótese do art. 345 e, ainda assim, não há presunção de veracidade dos fatos narrados pelo autor.

\section{a. Revelia e litisconsórcio}

No litisconsórcio, tem-se a diferenciação entre o regime comum e o especial, baseado nas diferentes relações entre os litisconsortes. Em regra, no litisconsórcio, prevalece a regra da independência entre os litisconsortes, de forma com que a conduta de um não possa interferir na do outro, situação que inclusive permanece consagrada na primeira parte do art. 117 do CPC, segundo o qual, "Os litisconsortes serão considerados, em suas relações com a parte adversa, como litigantes distintos". Esse é o regime comum do litisconsórcio.

No entanto, essa é uma regra dirigida ao regime comum do litisconsórcio. Caso seja hipótese de litisconsórcio unitário, os litisconsortes estarão envolvidos em uma relação jurídica incindível com diversos reflexos processuais, influenciando de que forma a conduta de um interfere na dos demais. Relembre-se que, no litisconsórcio unitário a decisão de mérito deve ser uniforme, fazendo com que seja necessária uma análise cuidadosa da eficácia de cada ato dos litisconsortes. Em tal situação tem-se o regime especial do litisconsórcio, regido pela segunda parte do art. 117 do CPC, segundo o qual, "no litisconsórcio unitário (...) os atos e as omissões de um não prejudicarão os outros, mas os poderão beneficiar". A disposição normativa não é tão simples e depende de aprofundamento doutrinário para que venha a fazer sentido.

Um conhecido critério de sistematização do regime geral do litisconsórcio foi desenvolvido por Barbosa Moreira. De um lado, tem-se os atos determinantes, que são aqueles a que a lei confere influência decisiva no desfecho do processo, podendo consistir em condutas comissivas ou omissivas. Por outro lado, existiriam as condutas alternativas, as quais não teriam aptidão para 


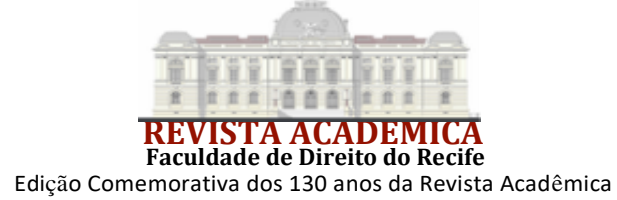

predeterminar, mesmo que parcialmente, o conteúdo da decisão final. As condutas alternativas seriam aquelas que buscam possibilitar condições para a conquista de uma situação de vantagem no processo, a exemplo do oferecimento da contestação, do ajuizamento de um recurso etc (DINAMARCO, 1997, p. 145). No caso do litisconsórcio unitário, as condutas determinantes, para produzirem efeitos típicos, dependeriam de que todos os litisconsortes a adotassem. Se apenas um deles, por exemplo, for revel, a revelia não produziria seus efeitos, diante da contestação de um ou mais litisconsortes (BARBOSA MOREIRA, 1972, p. 171-172). Também no litisconsórcio unitário, os comportamentos alternativos teriam a aptidão de estender os seus efeitos a todos os litisconsortes, mesmo que praticados por apenas um deles (BARBOSA MOREIRA, 1972, p. 161162). A lógica por trás do regime especial é a de manutenção da uniformidade da decisão de mérito. Em outros termos, ela atuará apenas sobre aqueles atos que possuem aptidão de colocar em risco o resultado do processo (EID, 2016, p. 173).

Pela classificação entre atos determinantes e alternativos, a revelia seria um ato determinante, por gerar uma consequência desfavorável, enquanto o oferecimento da contestação seria um ato alternativo, pelo potencial de melhora, mas não necessariamente ser capaz de fazê-lo.

De acordo com o art. 345, I, do CPC/2015, "A revelia não produz o efeito mencionado no art. 344 se: I - havendo pluralidade de réus, algum deles contestar a ação". O texto normativo não insere qualquer exigência acerca da espécie de litisconsórcio, interpretando-se que seja aplicável seja ao unitário, seja ao simples, desde que diga respeito a fato comum a todos os litisconsortes (BARBOSA MOREIRA, 1972, p. 223; DINAMARCO, 2017, p. 624; GIANESINI, 1977, p. 87; PONTES DE MIRANDA, 1997, p. 32; STJ, 4 ${ }^{\text {a }}$ T., AgRg no REsp 557.418/MG, Rel. Min. Antonio Carlos Ferreira, j. 02/04/2013, DJe 16/04/2013). Tem-se, aqui, uma situação em que o regime especial e o comum se comunicam quando haja fato comum.

\section{b. Revelia e direitos indisponíveis}

Os direitos indisponíveis, por não estarem na esfera de disponibilidade das partes, não sofrem os efeitos materiais da revelia. Nem sempre é fácil a identificação do que seriam direitos indisponíveis, mas é possível fazer menção a questões concernentes à filiação, à paternidade, interesses da criança ou adolescente (SOUZA, 2003, p. 207). No mesmo sentido, é possível mencionar os direitos da personalidade, que consta do art. 11 do CC (ROQUE, 2021, p. 478).

Em algumas situações, o STJ já se manifestou pela não incidência dos efeitos materiais da revelia, auxiliando na identificação desses direitos indisponíveis. Por exemplo, "A revelia em ação de divórcio na qual se pretende, também, a exclusão do patronímico adotado por ocasião do casamento não significa concordância tácita com a modificação do nome civil, por se tratar de direito indisponível" (STJ, $3^{\mathrm{a}}$ T., REsp 1.732.807-RJ, Rel. Min. Nancy Andrighi, por unanimidade, j. 14/08/2018, DJe 17/08/2018, info. n. 631). Note-se que o divórcio é direito disponível, mas não a modificação do nome civil, motivo pelo qual resta claro que os efeitos materiais da revelia podem incidir sobre parcelo do objeto do processo. Afinal, nada impede que haja direito disponível e direito indisponível em uma mesma relação processual.

Também já afirmou o STJ que "Sendo o direito de guarda dos filhos indisponível, não obstante admita transação a respeito de seu exercício, não há que se falar em presunção de veracidade dos fatos oriunda da revelia. Em outras palavras, a revelia na ação que envolve guarda de filho, por si só, não implica em renúncia tácita do requerido em relação à guarda compartilhada, por se tratar de direito indisponível" (STJ, 3 3 T., REsp 1.773.290/MT, Rel. Min. Marco Aurélio Bellizze, j. 21/05/2019, DJe 24/05/2019). Aqui importa relembrar que direito indisponível não significa direito que não pode ser objeto de transação.

\section{c. Efeitos materiais da revelia e Fazenda Pública}

Há inúmeras decisões do STJ que "não incidem os efeitos da revelia em face da Fazenda 


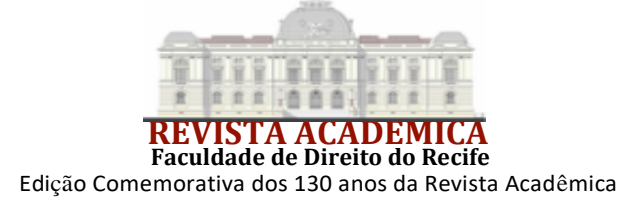

Pública, visto que seus bens e direitos são considerados indisponíveis" (STJ, $1^{\text {a }}$ Seção, AR 5.407/DF, Rel. Min. Napoleão Nunes Maia Filho, j. 10/04/2019, DJe 15/05/2019. Também assim: STJ, $1^{a}$ T., EDcl no AgRg no REsp 1.196.915/RJ, Rel. Min. Napoleão Nunes Maia Filho, j. 26/08/2019, DJe 28/08/2019). Portanto, em regra, os efeitos materiais da revelia não ocorrem quando a Fazenda Pública é ré porque o direito dela é indisponível, nos termos do art. 345, II, do CPC.

Ainda há quem aponte outro fundamento para não ocorrer o efeito material da revelia, que é a presunção de legitimidade dos atos do poder público. Assim, apesar da ausência de contestação, ainda caberia ao autor comprovar os fatos alegados (CUNHA, 2020, p. 97). Não se concorda com essa posição, pois a presunção de legitimidade tem por fundamento tão apenas o de permitir um certo poder executivo do poder público de atuar extrajudicialmente, podendo, por exemplo, fechar um estabelecimento pela inexistência de um alvará de funcionamento. Essa presunção, na verdade, não tem efeitos processuais, não alterando os encargos probatórios e nem os standards de prova (PEIXOTO, 2021a, p. 291-293). De toda forma, como a regra é a de que o direito do poder público é indisponível, mantém-se a regra da impossibilidade da produção dos efeitos materiais da revelia.

Naturalmente, existem algumas exceções a essa regra. Uma primeira e já consolidada existe no processo do trabalho, pois, de acordo com a OJ n. 152 do TST, "Pessoa jurídica de direito público sujeita-se à revelia prevista no artigo 844 da CLT". Do que se pode compreender essa posição existe porque entende o Poder Judiciário trabalhista que regra própria acerca das prerrogativas do poder público no Decreto-Lei n. 779/1969, que não afasta a revelia. Além disso, como o poder público, quando contrata de acordo com as normas da CLT, deixa de atuar com poder de império e atua como um empregador comum, sujeita-se às regras da CLT (art. 844). Por fim, como seria interesse patrimonial, o interesse público seria secundário, incidindo à revelia (MIESSA; CORREIRA, 2018, p. 1608).

Há um precedente do STJ, no recurso especial 1.084.745/MG que reconheceu a possibilidade da aplicação dos efeitos materiais da revelia nas ações contra o poder público "sempre que não estiver em litígio contrato genuinamente administrativo, mas sim uma obrigação de direito privado firmada pela Administração Pública" (STJ, 4ª T., REsp 1.084.745/MG, Rel. Min. Luis Felipe Salomão, j. 06/11/2012, DJe 30/11/2012).

Na situação específica, uma empresa tinha ajuizado ação de cobrança contra um município, cujo objeto era a locação de produtos da marca "xerox". Alegou que não ocorreu o pagamento das parcelas contratuais e, por isso, retomou os produtos e cobrou os valores devidos. O município foi revel e o STJ considerou tratar-se de um contrato particular, de direito privado e que, por isso, não haveria indisponibilidade do direito, nem relação de supremacia do poder público, atuando ele como um particular.

Além disso, apontou que o interesse em não pagar uma dívida não seria interesse público primário, mas apenas secundário. De toda forma, importante destacar que esse é um precedente isolado. Não se conhece precedentes mais recentes que tenham se utilizado desse mesmo raciocínio para permitir à revelia nas ações contra a Fazenda Pública.

De toda forma, trata-se de tema que requer maior aprofundamento, pois não parece mais compatível com o ordenamento jurídico a afirmativa de que o direito da Fazenda Pública sempre é indisponível.

Araken de Assis, por exemplo, afirma ser possível a incidência dos efeitos materiais da revelia em causas patrimoniais relativas ao Poder Público (2016, p. 1001). De forma semelhante outros autores também admitem a incidência dos efeitos materiais da revelia em relação ao interesse público secundário, relacionado com direitos de caráter patrimonial e que podem ser objeto de disposição (ROQUE, 2021, p. 478; YARSHELL; PEREIRA; RODRIGUES, 2018, art. 345, item 3). Um forte indicativo de situações nas quais o direito público não é indisponível ocorre nas mesmas situações nas quais poderá ser objeto de arbitragem, a qual só é admitida para direitos patrimoniais disponíveis (art. $1^{\circ}, \S 1^{\circ}$, da Lei 9.307/1996). Um ótimo indicativo de tais situações consta da Lei de Licitações e Contratos (Lei 14.133/2021), quando, ao reger os meios alternativos 


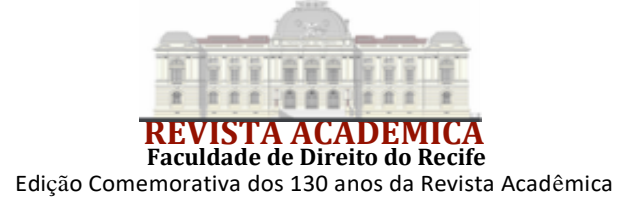

de resolução de controvérsias afirma, no parágrafo único do art. 151, que "Será aplicado o disposto no caput deste artigo às controvérsias relacionadas a direitos patrimoniais disponíveis, como as questões relacionadas ao restabelecimento do equilíbrio econômico-financeiro do contrato, ao inadimplemento de obrigações contratuais por quaisquer das partes e ao cálculo de indenizações".

\section{PETIÇÃO INICIAL DESACOMPANHADA DE INSTRUMENTO QUE A LEI CONSIDERE INDISPENSÁVEL À PROVA DO ATO}

Embora, em regra, haja ampla liberdade probatória, há situações nas quais a lei possa exigir um determinado meio de prova como requisito para que seja atingido o standard probatório para que uma hipótese fática seja tida como provada. São exemplos a exigência, no art. 108 do CC, da escritura pública para a comprovação da "validade dos negócios jurídicos que visem à constituição, transferência, modificação ou renúncia de direitos reais sobre imóveis de valor superior a trinta vezes o maior salário mínimo vigente no País", bem como o negócio jurídico que exige, para sua validade, a apresentação de instrumento público (art. 109 do CC). Nessas situações, mesmo que o réu não apresente a contestação tempestiva, não há presunção de veracidade dos fatos.

\section{a. Ausência de verossimilhança das alegações ou contradição com prova constante dos autos}

Consoante ressalta a doutrina, "a presunção de veracidade, a que se refere o art. 344 apenas se opera em relação às alegações de fato que se revista do requisito da credibilidade. (...) Em outras palavras, para se presumirem verdadeiros os fatos alegados pelo autor, em face da revelia do réu, devem estes passar pelo crivo da plausibilidade ou verossimilhança acentuada (CONCEIÇÃO, 2015, p. 938). Trata-se de uma limitação aos efeitos da revelia que está em consonância com o entendimento jurisprudencial de que a revelia não gera presunção absoluta de veracidade dos fatos alegados pelo autor.

Assim, por exemplo, se há uma narrativa que foge a razoabilidade, não é a revelia que a transformará em verdade, exigindo-se que haja apresentação de provas pela parte. Por exemplo, já afirmou o TST que, "Quando a jornada de trabalho declinada na inicial carecer de verossimilhança, a presunção de sua veracidade, decorrente da não apresentação de cartões de ponto, bem como da confissão ficta, deve ser afastada , cabendo ao órgão julgador arbitrar a jornada em observância ao princípio da razoabilidade". (RR-1743-09.2014.5.12.0030, 8a Turma, Relator Ministro Marcio Eurico Vitral Amaro, DEJT 11/04/2017). Imagine-se hipótese na qual o autor alegue que trabalhava de domingo a domingo, das $6 \mathrm{~h}$ às $23 \mathrm{~h}$, durante quatro anos. Trata-se de hipótese fática que não possui verossimilhança e a revelia não concede automaticamente veracidade a essa narrativa. Naturalmente, não é uma hipótese impossível de ocorrer, mas caberia ao autor se desincumbir do seu encargo probatório, comprovando que, efetivamente, exerceu essa jornada de trabalho, não bastando a simples revelia.

Em resumo, não se pode presumir o absurdo; a presunção da revelia não é absoluta e sim relativa.

\section{b. A revelia e a controvérsia fática em outras atuações dos sujeitos processuais}

Aparentemente, de acordo com o CPC, apenas é possível impedir os efeitos da revelia nas hipóteses previstas no art. 345. Ocorre que é possível uma leitura que impede a produção dos efeitos materiais da revelia a partir da utilização também do art. 341, que versa sobre a presunção relativa de veracidade dos fatos pela apresentação de contestação genérica. Em outros termos, a interpretação adequada envolve uma interpretação conjunta do art. 341 e do art. 345, impedindo que haja presunção relativa de veracidade dos fatos em todas as hipóteses desses dois textos 


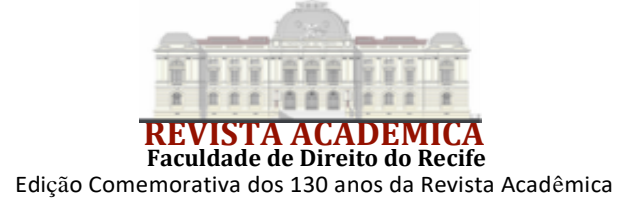

normativos. De acordo com o inciso III do art. 341, não há presunção de veracidade quando as alegações de fato da inicial "estiverem em contradição com a defesa, considerada em seu conjunto".

O termo defesa deve ser interpretado de forma ampla. Basta aqui imaginar o réu que apresenta manifestação prévia, impugnando todos os fatos alegados pelo autor, mas, por qualquer motivo, não apresenta contestação. Se a revelia é, de certa forma, uma sanção ao réu inerte (DINAMARCO, 2017, p. 629), não parece adequado que o réu sofra tamanho prejuízo pela simples não apresentação de contestação, se os fatos foram controvertidos em outro momento. Ou seja, o que importa é que os fatos sejam tornados controvertidos, mas não o instrumento utilizado para fazê-lo.

Da mesma forma, se o réu não contestar, mas apenas reconvém, se, na reconvenção, os fatos alegados pelo autor forem impugnados, não é adequada a presunção de veracidade dos fatos alegados pelo autor (DINAMARCO, 2017, p. 614). Afinal, se um litisconsorte impugna fato comum, não há o efeito material da revelia, seria ainda mais justificado que esse efeito fosse impedido pelo próprio autor em manifestação protocolada no prazo da contestação.

Semelhante conclusão é obtida por autores que interpretam que o réu apenas será revel se eles não se manifestar de nenhuma forma que instaure a controvérsia sobre os fatos (YARSHELL; PEREIRA; RODRIGUES, 2018, art. 344, item 1). Não se concorda com a interpretação dada ao fenômeno da revelia, que, pela legislação ocorre, pela não apresentação de contestação. No entanto, como a revelia é diversa da produção dos seus efeitos, nada impede que o réu seja revel, mas não sofra os efeitos da revelia, como defendido nesse item.

\section{c. Efeitos materiais da revelia e a possibilidade do ajuizamento de uma ação declaratória negativa}

O processualista Bruno Silveira de Oliveira (2007, p. 351-367) possui interessante posicionamento que permite, de certa forma, elidir a presunção de veracidade gerada pela revelia. Para o autor, por exemplo, em ação de cobrança, mesmo que o réu não apresentasse a contestação de forma tempestiva, poderia ajuizar uma "demanda declaratória negativa de débito", na qual a causa de pedir fosse a inexistência do fato alegado como causa petendi ativa da ação de cobrança e que tenha como pedido uma declaração de que o seu autor não tem a obrigação de pagar aquele débito.

Afirma-se que essa outra demanda não teria o óbice da litispendência, uma vez que os pedidos são inegavelmente diferentes (condenatória e declaratório negativo), assim como o são as causas de pedir. Mais ainda, seria correta a distribuição por dependência e o recebimento da demanda como contestação, pois pouco importa a denominação da peça « mas sim o seu objetivo.

Com fundamento nesse raciocínio, aponta que a contestação, mesmo intempestiva, deve ser recebida, gerando a controvérsia sobre os fatos e impedindo os efeitos materiais da revelia. Afinal, não haveria fundamentos para impedir que essa mesma pretensão fosse exercida por meio de ação autônoma, pois a regra que impede a apresentação da contestação intempestiva não poderia impedir o exercício do direito de ação, derivado diretamente da constituição. Negar o recebimento dessa ação declaratória como contestação apenas iria gerar o risco de incompatibilidade prática entre os julgadores, acarretando desperdício de tempo do Poder Judiciário.

A crítica a esse posicionamento é realizada por Fredie Didier Jr (2015, p. 63). Na verdade, a demanda ajuizada pelo réu seria obstada pela litispendência. Isso porque a simples improcedência na demanda originária deve ser tida como um "juízo de não acolhimento do pedido formulado pelo demandante" (2015, p. 63) porque ela vem "incluída" na demanda originária. É nesse sentido que essa demanda negativa dos fatos do autor ajuizada pelo réu, cujo resultado, se positiva, resultaria na mesma resposta obtida pela improcedência da demanda originária deve ser impedida pela litispendência. Admitir a ação proposta pelo réu é o mesmo que "apresentar ao Poder Judiciário a mesma situação jurídica já a ele anteriormente submetida” (DIDIER JR., 2015, p. 63). 


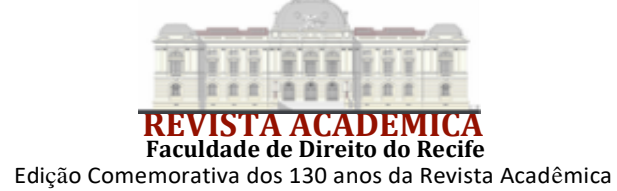

Em outros termos, há litispendência porque, mesmo que a causa de pedir o pedido sejam exatamente o contrário do que é formulado pelo autor originário, essa contrariedade está incluída na demanda originária, mesmo que de forma implícita.

\section{d. Outros limites dos efeitos materiais da revelia}

\section{i. Revelia e valor dos danos}

Como já decidido pelo STJ, mesmo que reconhecida a revelia, "a presunção de veracidade quanto aos danos narrados na petição inicial não alcança a definição do quantum indenizatório indicado pelo autor" (STJ, 4 ${ }^{\mathrm{a}}$ T., REsp 1.520.659-RJ, Rel. Min. Raul Araújo, j. 1\%10/2015, DJe 30/11/2015, info. n. 574). O que acontece, nessa situação, é a presunção de veracidade de que os fatos ocorreram tal e qual narrados pelo autor, por exemplo, de que o réu é culpado pelo acidente entre os veículos. Mas ele não gera uma presunção de veracidade do valor da indenização pedida.

Se o veículo do autor é um Gol, carro popular, não se pode admitir que haja requerimento de indenização por danos materiais no valor de $\mathrm{R} \$ 1.000 .000,000$. Da mesma forma, se no acidente entre os veículos, o autor sofreu mera escoriações, não se poderia admitir um pedido de indenização de danos morais no valor de $\mathrm{R} \$ 500.000,00$. O valor do dano será devidamente avaliado pelo juiz a partir da narrativa fática da parte, sendo a quantificação indicada pelo autor apenas um elemento indicativo e limitativo, no sentido de que não pode ser ultrapassado.

\section{ii. A revelia e o direito}

Como corretamente destaca Dinamarco (2017, p. 619) "Nenhuma presunção incide sobre o direito", incidindo a revelia apenas quanto aos fatos. Se, por exemplo, a parte cobra uma dívida de jogo, por mais que o réu não conteste e incidam os efeitos materiais da revelia, o pedido deve ser julgado improcedente. Afinal, de acordo com o art. 814 do CC, "As dívidas de jogo ou de aposta não obrigam a pagamento". Assim, mesmo que haja produção dos efeitos materiais da revelia, presumindo-se a existência da dívida, ainda há necessidade de verificação de autorização legal para a procedência do pedido.

\section{LIMITES DA REVELIA EM PROCEDIMENTOS ESPECIAIS}

\subsection{REVELIA E AÇÃO RESCISÓRIA}

Os efeitos materiais da revelia não incidem no caso de ausência de contestação na ação rescisória. Isso porque as presunções advindas do título executivo, bem como da eficácia preclusiva da coisa julgada prevalecem sobre eventuais efeitos materiais (ARAÚJO, 2020b, p. 226). Há quem sustente a mesma conclusão tendo por base o interesse público na manutenção da coisa julgada (SOUZA, 1995, item 9.7). Essa é também a posição do STJ, afirmando que, mesmo na ausência de contestação, prevalece o princípio da preservação da coisa julgada (STJ, $2^{\text {a }}$ Seção, AgRg na AR 3.867/PE, Rel. Min. Marco Buzzi, j. 12/11/2014, DJe 19/11/2014).

Há posição em sentido contrário, afirmando que apenas não haveria revelia no juízo rescindente, mas seria possível a incidência dos efeitos materiais no que se refere ao juízo rescisório, por não haver qualquer previsão legal que o exclua (YARSHELL; PEREIRA; RODRIGUES, 2018, art. 345, item 7). No entanto, apesar da inexistência de previsão expressa que a exclua, parece possível extrair a impossibilidade da presunção de veracidade dos fatos das presunções que são advindas da existência de um título executivo judicial, bem como da eficácia preclusiva da coisa julgada, como defendido por José Henrique Mouta Araújo (2020b, p. 226). 


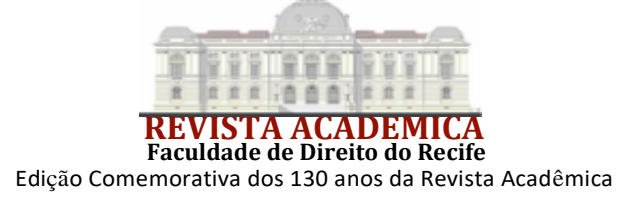

\subsection{REVELIA E MANDADO DE SEGURANÇA}

No mandado de segurança, não há, propriamente, a apresentação de contestação, mas apenas são prestadas informações pela autoridade coatora. De toda forma, é importante questionar se a não apresentação dessas informações gera efeitos processuais, a exemplo da presunção de veracidade. A resposta mais adequada parece ser a de que não há presunção de veracidade nesse caso.

Isso porque, inicialmente, a autoridade coatora não é parte, mas sim a pessoa jurídica, a qual irá sofrer as consequências financeiras e operacionais da decisão (PEIXOTO, 2021, p. 274). Em decorrência dessa premissa, a natureza jurídica das informações da autoridade coatora não pode ser tecnicamente de que é uma defesa, porque ela é prestada pela autoridade, que não é parte.

Do ponto de vista da natureza jurídica, as informações prestadas pela autoridade devem ser consideradas como um meio de prova e a autoridade como um informante (ARAÚJO, 2020a, p. 312). Uma consequência importante é a de que a ausência das informações não gera os efeitos da revelia, não se presumindo verdadeiros os fatos alegados pelo autor (STJ, ${ }^{\text {a }}$ T., RMS 26.170/RO, Rel. Min. Francisco Falcão, j. 04/12/2008, DJe 15/12/2008; STJ, $4^{\mathrm{a}}{ }^{T}$ T., RMS 11.571/SP, Rel. Min. Sálvio De Figueiredo Teixeira, j. 13/09/2000, DJ 23/10/2000). Essa é também a opinião da doutrina (ARAÚJO, 2020b, p. 229).

8.3 REVELIA E DESAPROPRIAÇÃO

Na desapropriação, o objeto da discussão cinge-se, basicamente, ao preço a ser pago pelo poder público. Isso porque, por exemplo, o art. 20 do Decreto-lei 3.365/1941 limita a defesa do réu a vícios do processo judicial e impugnação do preço. Outras questões devem ser objeto de ação direta.

A discussão, então, sobre os efeitos materiais da revelia envolvem, no fim das contas, se o valor indicado pelo poder público será presumido como correto. A resposta é negativa, uma vez que na desapropriação, só não haverá perícia em relação ao preço se o réu concordar expressamente com o preço (art. 23 do Decreto-lei 3.365/1941). E, sendo o réu revel, por motivos óbvios, não houve manifestação, não houve concordância.

Esse já era o entendimento consolidado na súmula 118 do extinto TRF, "a ação expropriatória a revelia do expropriado não implica em aceitação do valor da oferta, e, por isso, não autoriza a dispensa da avaliação", a qual vem sendo aplicada pelo STJ (STJ, 2a T., REsp 1.437.557/CE, Rel. Min. Assusete Magalhães, j. 09/06/2020, DJe 17/06/2020). Na doutrina também parece prevalecer essa posição (CUNHA, 2020, p. 824-825; ARAÚJO, 2020b, p. 230231). Em resumo, a perícia é sempre obrigatória, exceto se o réu concordar com o valor proposta pela administração pública.

\section{EFEITOS PROCESSUAIS DA REVELIA}

Os efeitos processuais estão regulados no art. 346, segundo o qual os prazos contra o revel que não tenha patrono nos autos fluirão da data de publicação do ato decisório no órgão oficial.

Inicialmente, é importante diferenciar publicação de intimação. A publicação do ato ocorre no momento em que a decisão sai da intimidade do julgador e é juntada aos autos ou proferida em audiência. A intimação, por sua vez, consiste em ato de comunicação processual. Como destaca a doutrina, "publicar é 'tornar público', ao passo que intimar é 'dar ciência' (YARSHELL; PEREIRA; RODRIGUES, 2018, art. 346, item 1).

Uma primeira observação é a de que nem todo réu sofrerá os efeitos processuais. Isso porque só há a dispensa de intimação quando o réu não tem patrono nos autos (art. 346, CPC). Assim, se, por exemplo, o juiz permitiu manifestação sobre pedido de tutela provisória e o réu a 
apresentou por meio do seu patrono, não incidirá esse efeito processual da revelia, porque ele terá patrono nos autos.

\section{LIMITES AOS EFEITOS PROCESSUAIS DA REVELIA}

\subsection{FORMA DE CITAÇÃO}

A incidência dos efeitos processuais da revelia apenas ocorrerá se o réu houver sido citado pessoalmente. Isso porque, caso a citação tenha sido ficta (por hora certa ou edital), haverá nomeação de curador especial (art. 72, II, CPC), que será regularmente intimado das decisões (CRUZ E TUCCI, 2016, p. 257). Como apontado no item 3.2, a citação há de ser real.

\subsection{DIREITO PERSONALÍSSIMOS}

Apesar da previsão do CPC, no sentido de dispensar a intimação do réu revel, existem alguns atos que, apesar da revelia, dependem da comunicação ao réu para produzirem efeitos. Um importante exemplo são os atos personalíssimos, dos quais são exemplos a intimação para prestar depoimento pessoal (art. 385, $\S 1^{\circ}$ ), a intimação para a exibição de documento ou coisa (art. 398) etc.

\subsection{RÉU REVEL E INTIMAÇÕES NA FASE DE CUMPRIMENTO DE SENTENÇA}

Não há menção expressa na legislação à forma de intimação do réu revel sem procurador nos autos, quando essa situação permanece até a fase de cumprimento de sentença. Para parte da doutrina, mantém-se o efeito processual da revelia, uma vez que o cumprimento de sentença é apenas uma fase do processo de conhecimento (ROQUE, 2021, item 7).

Há, no entanto, uma situação específica que requer análise mais profundada, que é a forma de intimação para o cumprimento espontâneo, nos termos do art. 513, §2 $2^{\circ}$, do CPC. Uma primeira observação específica refere-se ao réu revel citado por edital, no qual há regra específica. Como observado no item 3, esse réu terá curador especial, que será intimado dos atos praticados no processo, no entanto, o legislador considerou que essa intimação não seria suficiente. Por conta disso, previu que, sendo o réu revel citado por edital, será intimado para cumprir a sentença novamente por edital (art. 513, §2, IV, CPC).

Embora não haja menção expressa, parece-nos que também incidirão as hipóteses do art. $513, \S 2^{\circ}$, I e II, a depender da situação concreta. Importa recordar que o curador especial é a pessoa designada pelo magistrado para representar a parte em juízo, detendo os mesmos poderes e direitos da parte (ARAKEN, 2015, p. 151). Em regra, a curadoria especial será realizada pela defensoria pública (art. 72, parágrafo único, do CPC) e, nesses casos, ela deverá ser intimada para cumprir a sentença por meio de carta com aviso de recebimento (art. 513, §2 ${ }^{\circ}$ II, CPC). Caso não seja possível o exercício da curadoria especial pela defensoria pública, deverá ser designado advogado dativo, ${ }^{4}$ hipótese na qual incidirá o art. $513, \S 2^{\circ}$, I, do CPC, com intimação do advogado por meio do Diário de Justiça.

Por outro lado, não há uma previsão específica para os casos em que o réu revel tenha sido citado pessoalmente. Para o STJ, "Em se tratando de parte sem procurador constituído, aí incluindo-se o revel que tenha sido pessoalmente intimado, quedando-se inerte, o inciso II do $\S 2^{\circ}$ do art. 513 do CPC fora claro ao reconhecer que a intimação do devedor para cumprir a sentença

4 “A inexistência, em determinada comarca, de órgão da Defensoria Pública do Estado para exercer a curadoria especial deve ser suprida segundo as normas locais que regulamentam a sua organização e o seu funcionamento e, na impossibilidade de tal suprimento, há de ser designado advogado dativo". (STJ, $3^{\mathrm{a}}$ T., REsp 1.824.208/BA, Rel. Min. Nancy Andrighi, j. 10/12/2019, DJe 13/12/2019) 


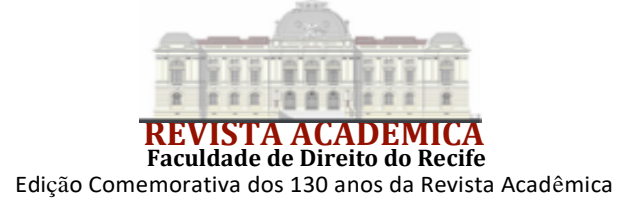

ocorrerá "por carta com aviso de recebimento". (STJ, $3^{\mathrm{a}}$ T., REsp 1.760.914/SP, Rel. Min. Paulo De Tarso Sanseverino, j. 02/06/2020, DJe 08/06/2020). Há entendimento doutrinário no mesmo sentido: YARSHELL; PEREIRA; RODRIGUES, 2018, art. 346, item 5.

Essa decisão foi criticada por parte da doutrina, sob o fundamento de que essa forma de intimação seria uma simples regra geral, que inclui os casos de revogação ou renuncia à procuração pelo advogado. O seu objetivo não seria aumentar a proteção jurídica do réu revel, não sendo capaz de afastar a regra contida no art. 346 do CPC (ROQUE, 2021, item 7).

Essa não é a melhor interpretação da questão. Por mais que o cumprimento de sentença seja uma fase do processo de conhecimento, ela só ocorre quando encerrada a fase cognitiva. Ou seja, tratase da fase executiva, na qual predominam os atos materiais, por óbvio, gravosos ao réu. É plenamente justificável a incidência do art. $513, \S 2^{\circ}$, II, do CPC, determinando a citação por correio do réu revel na fase cognitiva, até como uma forma de densificar a incidência do contraditório, incentivando o réu a participar do processo. Até porque, se na fase cognitiva é possível o andamento do processo sem a participação do réu, na fase de cumprimento de sentença, a sua atuação será necessária. Além disso, por mais que seja possível interpretar que se trata de uma regra geral, que pode incidir para réus não revéis nas quais ocorreu revogação da procuração, tratase de regra específica para a fase executiva do processo de conhecimento. Não havendo regra específica de intimação do réu revel citado pessoalmente para essa intimação específica, deve prevalecer a regra do art. $513, \S 2^{\circ}$, II.

\section{INTERVENÇÃO DO RÉU NO PROCESSO E CONSEQUÊNCIAS PROCESSUAIS}

Mesmo que não haja patrono nos autos, o efeito processual da revelia poderá ser limitado por atuação posterior do réu revel que passe a ter patrono nos autos. É exatamente essa a previsão do parágrafo único do art. 346, que permite ao réu intervir nos autos em qualquer momento. Obviamente, como receberá o processo no estado em que se encontrar, ele não será intimado das decisões anteriores, mas o será a partir do momento em que intervir no processo.

Para além de passar a ser intimado dos atos, o réu revel passa a poder atuar no processo, interpondo recursos e participando como qualquer outra parte. Poderá, inclusive, participar da produção de provas, consoante expressamente autorizado pelo art. 349 do CPC. No entanto, essa produção de provas deve ser limitada, uma vez que a não apresentação tempestiva da contestação conduz à incontroversia dos fatos, dispensando-os de prova (art. 374, III, CPC).

Como ressalta a doutrina, a produção de provas só deve ser admitida se ocorrer uma das situações do art. 345, do contrário, seria fazer letra morta das disposições que produzem o efeito material da revelia (YARSHELL; PEREIRA; RODRIGUES, 2018, art. 346, item 3), bem como a incontroversia dos fatos. Do contrário, seria completamente irrelevante a revelia, pois bastaria o réu controverter os fatos em outro momento, requerendo a produção de provas.

\section{CONSIDERAÇÕES FINAIS}

Como visto, a revelia tem dois efeitos principais, um material, que consiste na presunção relativa de veracidade dos fatos narrados pelo autor, e um processual, que dispensa a intimação do réu em relação aos atos decisórios. Ocorre que todos esses efeitos, apesar de drásticos podem ser limitados a depende da situação concreta dos autos.

Em relação aos efeitos materiais, que são os mais prejudiciais, percebe-se uma ampla limitação da produção dos seus efeitos, desde a ausência de credibilidade dos fatos narrados pelo autor, até pelo fato de outro litisconsorte impugnar esses fatos ou mesmo a própria parte já tê-los tornados controvertidos em outro momento. Percebe-se também as limitações da presunção de veracidade dos fatos, pois a eles é limitada, não significando, de forma alguma, em reconhecimento do pedido. Nada impede que os fatos sejam tidos como verdadeiros, mas não haja autorização legal para a procedência do pedido. Mais ainda, em diversos procedimentos especiais, é possível 
verificar que existem óbices a uma ampla incidência dos efeitos materiais da revelia, como ocorre, por exemplo, na desapropriação, na ação rescisória e no mandado de segurança.

Por sua vez, os efeitos processuais da revelia podem ser impedidos por conduta até prévia do réu, bastando que tenha advogado constituído nos autos. Para além disso, trata-se de efeito que pode ser elidido a qualquer momento, bastando que o réu compareça aos autos para que passe a necessariamente ser intimado dos atos decisórios.

\section{REFERENCIAS}

ARAÚJO, José Henrique Mouta. A teoria da encampação no procedimento do mandado de segurança e o entendimento do STJ. Revista de Processo, n. 302, abr. 2020a.

ARAÚJO, José Henrique Mouta. Revelia e as consequências diferenciadas na ação rescisória, mandado de segurança e desapropriação. Revista Brasileira de Direito Processual, n. 110, abr./jun. 2020b.

ASSIS, Araken de. Processo civil brasileiro. 2. ed. São Paulo: RT, 2016. v. 1.

ASSIS, Araken de. Processo civil brasileiro. São Paulo: RT, 2015. v. 2. t. 1.

ASSIS, Araken de. Processo civil brasileiro. São Paulo: RT, 2015. v. 3.

BARBOSA MOREIRA, José Carlos. Litisconsórcio unitário. Rio de Janeiro: Forense, 1972.

BEDAQUE, José Robertos dos Santos. Efetividade do processo e técnica processual. São Paulo: Malheiros, 2006.

CONCEIÇÃO, Maria Lúcia Lins. Comentários ao art. 344. In: DIDIER JR., Fredie et al. Breves comentários ao código de processo civil. São Paulo: RT, 2015.

CRUZ E TUCCI, José Rogério. Comentários ao código de processo civil. São Paulo: Saraiva, 2016. v. 7.

CUNHA, Leonardo José Carneiro da. A contumácia das partes como ato-fato processual. In: DIDIER JR., Fredie; NOGUEIRA, Pedro Henrique; GOUVEIA FILHO, Roberto P. Campos (coords). Pontes de Miranda e o direito processual. Salvador: Juspodivm, 2013.

CUNHA, Leonardo Carneiro da. A fazenda pública em juízo. 17 ed. Rio de Janeiro: Forense, 2020 .

DIDIER JR., Fredie. Contradireitos, objeto litigioso do processo e improcedência no CPC-2015. In: MOUZALAS, Rinaldo; SILVA, Beclaute Oliveira; MARINHO, Rodrigo (coord.).

Improcedência. Salvador: Juspodivm, 2015.

DIDIER JR., Fredie. Curso de direito processual civil. 20. ed. Salvador: Juspodivm, 2018. v. 1.

DINAMARCO, Cândido Rangel. Instituições de direito processual civil. 7. ed. São Paulo:

Malheiros, 2017, v. 3.

DINAMARCO, Cândido Rangel. Litisconsórcio. 5. ed. São Paulo: Malheiros, 1997. 
EID, Elie Pierre. Litisconsórcio unitário. São Paulo: RT, 2016.

GIANESINI, Rita. Da revelia no processo civil brasileiro. São Paulo: RT, 1977.

MIESSA, Élisson; CORREIRA, Henrique. Súmulas e OJs do TST comentadas e organizadas por assunto. 8. ed. Salvador: Juspodivm, 2018.

OLIVEIRA, Bruno Silveira de. Conexidade e efetividade processual. São Paulo: RT, 2007.

PEIXOTO, Ravi. Diálogos da fazenda pública em juízo. Salvador: Juspodivm, 2021b.

PEIXOTO, Ravi. Standards probatórios no direito processual brasileiro. Salvador: Juspodivm, $2021 \mathrm{a}$.

PONTES DE MIRANDA, Francisco Cavalcanti de. Comentários ao código de processo civil. 3. ed. Rio de Janeiro: Forense, 1997.

ROQUE, Andre. Revelia. GAJARDONI, Fernando; ROQUE, Andre; DELLORE, Luiz; OLIVEIRA JR., Zulmar Duarte de. Comentários ao código de processo civil. 4. ed. São Paulo: Método, 2021. versão digital.

SOUZA, Artur César de. A revelia no processo civil. São Paulo: RT, 2003.

SOUZA, Gelson Amaro de. Da revelia. Revista de Processo, v. 80, out./dez.1995. Versão eletrônica.

YARSHELL, Flávio Luiz; PEREIRA, Guilherme Setoguti J.; RODRIGUES, Viviane Siqueira. Comentários ao código de processo civil. São Paulo: RT, 2018. t. 5. Versão eletrônica. 